\title{
ВПЛИВ ПОЛІПШЕННЯ МУЛЬТИКАТУРНОЇ КОМПЕТЕНТНОСТІ ЗДОБУВАЧІВ ВИЩОЇ ОСВІТИ ТА ФАХІВЦІВ ПІДПРИЄМСТВ НА МАРКЕТИНГОВУ ДІЯЛЬНІСТЬ В СФЕРІ ГОСТИННОСТІ
}

\section{THE IMPACT OF IMPROVING THE MULTICATURAL COMPETENCE OF STUDENTS AND ENTERPRISE SPECIALISTS ON MARKETING ACTIVITIES IN THE FIELD OF HOSPITALITY}

\author{
Олійник Ольга Степанівна \\ кандидат економічних наук, доцент, \\ Кам'янець-Подільський національний університет імені Івана Огієнка \\ ORCID: https://orcid.org/0000-0003-2370-3211 \\ Oliinyk Olha \\ Kamenets-Podolsky National University named after Ivan Ogienko
}

\begin{abstract}
В статті досліджено ряд відповідних понять, а саме - компетентність, адаптивне управління, мультикультурна компетентність. Звернена увага на дію поліпшення мультикатурної компетентності здобувачів вищої освіти в подальшому на маркетингову діяльність в сфері гостинності. Вказано на існування онлайн-навчальних програм, які пропонують можливості для взаємодії та роздумів та можуть відобразити концепцію культурного та мовного розмаїття великій кількості співробітників. Зроблений аналіз наявних закладів вищої освіти в Україні. А також, звернена увага на кількість здобувачів вищої освіти, що навчаються за державний кошт і їх зв'язок з кількістю абітурієнтів. Звернена увага на питання професійного самовдосконалення викладачів, щодо мотивації зростання викладача, як основного чинника підвищення продуктивності праці.
\end{abstract}

Ключові слова: компетентність, адаптивне управління, мультикультурна компетентність, підготовка фрахівців, сфрера гостинності.

В статье исследованы ряд соответствующих понятий, а именно - компетентность, адаптивное управление, мультикультурная компетентность. Обратите внимание на действие улучшения мультикатурной компетентности соискателей высшего образования в дальнейшем на маркетинговую деятельность в сфере гостеприимства. Указано на существование онлайн учебных программ, которые предлагают возможности для взаимодействия и размышлений и могут отразить концепцию культурного и языкового разнообразия большого количества сотрудников. Проведен анализ имеющихся учреждений высшего образования в Украине. А также обращено внимание на количество соискателей высшего образования, обучающихся за государственные средства и их связь с количеством абитуриентов. Обращено внимание на вопросы профессионального самосовершенствования преподавателей, мотивации роста преподавателя, как основного фрактора повышения производительности труда.

Ключевые слова: компетентность, адаптивное управление, мультикультурная компетентность, подготовка специалистов, сфера гостеприимства.

The article explores a number of relevant concepts, namely - competence, adaptive management, multicultural competence. Attention is paid to the effect of improving the multicultural competence of higher education seekers in the future on marketing activities in the field of hospitality. There is no standard way of teaching cultural competence, and different programs are suitable for different organizations based on available levels of multicultural skills, work needs and joint activities. Some high-quality programs and teachers offer different methods, content, format and duration. Although good cultural education programs may seem different, they have much in common. Good multicultural training is based on evidence, research and experience. Organizations that truly value their cultural potential must be able to set academic goals and objectives. Some organizations may need a familiarization program to train staff on broad topics and concepts, while others may need practical tools and strategies to develop diverse employees or improve customer service. Good multicultural knowledge programs clearly demonstrate how they meet the needs of the organization or students. They clearly define the results that organizations and individuals can 
expect. Regardless of the method used, quality training programs give participants the opportunity to interact with ideas and concepts and reflect. They also include setting goals for personal or organizational change and proposing further action or evaluation. The existence of online training programs that offer opportunities for interaction and reflection and can reflect the concept of cultural and linguistic diversity to a large number of employees is pointed out. The analysis of existing higher education institutions in Ukraine is made. Also, attention was paid to the number of applicants for higher education studying at public expense and their relationship with the number of applicants. Attention is paid to the issues of professional self-improvement of teachers, to motivate the growth of teachers as the main factor in increasing productivity.

Keywords: competence, adaptive management, multicultural competence, training, hospitality.

Постановка проблема. В сучасних умовах господарювання на підприємствах гостинності постало гостро питання успішного просування туристичних продуктів та послуг. Дана ситуація $є$ наслідком низки проблем та питань. Однією такою проблемою є рівень квалісрікації фахівців даної галузі і відповідно їх підготовка. В часи незалежності України в багатьох вищих навчальних закладах почати готувати даних фрахівців. В процесі підготовки фрахівців сфрери гостинності почали виникати питання наявності відповідних компетенцій. В результаті дослідження науково-педагогічні працівники навчальних закладів прийшли до висновку, що необхідно звернути особливу увагу на мультикатурну компетентність здобувачів вищої освіти для покращення результатів маркетингової діяльності в сорері гостинності.

Аналіз останніх досліджень і публікацій. В сучасній науковій літературі накопичений науковий і практичний досвід з проблематики віддзеркалення мультикатурної компетентності здобувачів вищої освіти для покращення результатів маркетингової діяльності на підприємствах. В результаті чого виявлено, що даною проблемою займається ряд науковців, до прикладу: Ізбаш С., Бутурліна Ю., Борова Т., Єльникова Г. та інші. Науковці підкреслюють перспективи розвитку працевлаштування фрахівців, даної галузі гостинності, а також вони вказують, що необхідно проводити додаткові дослідження у напрямку поліпшення мультикатурної компетентності здобувачів вищої освіти.

Метою статті $є$ уточнення сутності «компетентність», стан підготовки майбутніх фрахівців сорери гостинності покращення результатів маркетингової діяльності підприємств.

Враховуючи, що діяльність всіх суб'єктів діяльності ґрунтується на законодавчих актах, хочеться відмітити, що в Законі України «Про освіту» дане визначення терміну «компетентність», отже «компетентність» динамічна комбінація знань, умінь, навичок, способів мислення, поглядів, цінностей, інших особистих якостей, що визначає здат- ність особи успішно соціалізуватися, провадити професійну та/або подальшу навчальну діяльність [1]. Для проведення успішної підготовки фрахівців викладачі повинні володіти відповідними компетентностями. В вище згаданому Законі відмічене те, що: профресійний розвиток педагогічних і науково-педагогічних працівників передбачає постійну самоосвіту, участь у програмах підвищення квалісікації та будь які інші види і фрорми профресійного зростання. Заклади освіти, в яких працюють педагогічні та науково-педагогічні працівники, сприяють їхньому професійному розвитку та підвищенню кваліфрікації [1]. Педагогічні, науково-педагогічні та наукові працівники зобов'язані: постійно підвищувати свій профресійний і загальнокультурний рівні та педагогічну майстерність [1].

Під час розгляду питань профресійного самовдосконалення педагогів особливу увагу необхідно приділяти мотивації зростання вчителя як основного чинника підвищення продуктивності праці [2].

Під час навчання в закладах освіти, а також під час проходження практик необхідно здійснювати адаптивне управління 3 метою покращення підготовки. В свою чергу, адаптивне управління, це - системне, багатовимірне та багаторівневе управління, яке охоплює всі елементи педагогічної системи, узгоджує процеси управління й самоуправління, зовнішні вимоги та внутрішні мотиви учасників навчального процесу, створює простір для творчої конкретизації педагогічної діяльності відповідно до реальної ситуації при збереженні стратегічних напрямів, сприяє саморозвитку та самореалізації адміністрації, педагогічного та учнівського колективів [3].

Рушійним фрактором розвитку такої управлінської системи $є$ баланс інтересів усіх її учасників і підструктур [4]. Якщо спрямована самоорганізація реалізує саморозвиток людини в усталених межах усвідомлених нею вимог, то адаптивне управління забезпечує умови для саморозвитку людини шляхом поєднання її потреб з вимогами оточення [4]. 
Мультикультурна компетентність - це здатність ефективно розуміти, спілкуватися та спілкуватися з людьми різних культур. Мультикультурна компетентність має як організаційний, так і особистісний виміри.

Розвиток полікультурного потенціалу вимагає усвідомлення культурних ідей, цінностей і вірувань. Це демонструє наше розуміння того, що культура формує наш світогляд і що люди бачать світ по-іншому. Знайомство 3 різними культурами передбачає розуміння того, що люди мають різні потреби. Удосконалення мультикультурних компетенцій може призвести до ефективнішого та ефрективнішого спілкування 3 людьми різного культурного та мовного походження. На університетському рівні мультикультурні знання включають розробку систем, політики та методів для забезпечення культурного різноманіття в усіх аспектах роботи. Університетські профрспілки використовують культурне різноманіття для ефективного прийняття рішень, креативності та адаптивності, щоб створити різноманітну та успішну робочу силу з високим рівнем культурного розмаїття. Не існує стандартного способу навчання культурної компетентності, і різні програми підходять для різних організацій на основі наявних рівнів мультикультурних здібностей, робочих потреб і спільних заходів. Деякі високоякісні програми та викладачі пропонують різні методи, зміст, фрормат і тривалість. Хоча хороші програми навчання культурних знань можуть здатися різними, вони мають багато спільного. Хороша мультикультурна підготовка базується на доказах, дослідженнях та досвіді. Не всі навчальні програми мають однакову академічну перспективу, але хороші навчальні програми включають сутність доказів і основу послідовного бачення. Вони базуються на новітній інформації та дослідженнях із низки надійних джерел. У навчальній програмі багатокультурних знань чітко визначено структуру, теорії та концепції, які мають бути охоплені, результати, які необхідно досягти, прогнозовані вигоди для окремих осіб та організацій, а також задіяні ресурси. Згадайте переваги культурного різноманіття. без розрізнення окремих груп негативних думок, які не використовують єдину мову. Позитивне мультикультурне навчання заохочує учасників розуміти, що робити з припущеннями про культурні впливи чи контури. Це стимулює розвиток позитивного ставлення до культурного та мовного розмаїття, ідей справедливості та інклюзії, а також усунення бар'єрів за допомогою паралельних досліджень. Позитивне навчання сприяє постійному та чуйному спілкуванню та наголошує на особистій рефрлексії як важливому чиннику розвитку багатокультурних знань. Організації, які справді цінують свій культурний потенціал, повинні мати можливість встановлювати академічні цілі та завдання. Деяким організаціям може знадобитися ознайомлювальна програма для навчання персоналу широким темам і концепціям, тоді як іншим потрібні практичні інструменти та стратегії для розвитку різноманітних співробітників або підвищення ефрективності роботи 3 клієнтами. Хороші мультикультурні програми знань чітко демонструють, як вони задовольняють потреби організації чи студентів. Вони чітко визначають результати, на які можуть очікувати організації та окремі особи.

Незалежно від використовуваного методу, якісні навчальні програми дають учасникам можливість взаємодіяти з ідеями та концепціями та роздумувати. Вони також включають встановлення цілей для особистих або організаційних змін і пропозицію подальших дій або оцінку.

Існують високоякісні онлайн-навчальні програми, які пропонують можливості для взаємодії та роздумів, хоча онлайн-програми ідеально підходять для навчання в класі. Онлайн-програми можуть представити концепцію культурного та мовного розмаїття великій кількості співробітників і $€$ ознакою того, що організація цінує різноманітність. Однак, за словами австралійського комісара 3 питань дискримінації, найкращий підхід - змінити досвід людей. Взаємодія обличчям до обличчя часто змінює досвід, оскільки є можливість для обговорення, запитань і повторення роздумів. Викладено у професійному, цікавому та доступному форматі. Навчання мультикультурним знанням може включати компактний зміст і тверді поняття. Для ефективної комунікації та гарної культурної компетенції матеріали були представлені в цікавій формі для учасників навчальних програм. Включає оцінку до та після навчання. Базове оцінювання означає, що зміст навчальної програми може бути належним чином адаптований і дозволяє постачальникам вищої освіти оцінювати існуючі рівні полікультурних знань. Опитування якості та методи оцінювання також надають як якісні, так і кількісні дані для вимірювання ефективності навчання. Хоча для обізнаних вчителів різних культур немає специфрічних характеристик, вони мають ряд навичок і характеристик, якими можна поділи- 
тися. Кваліфріковані тренери можуть створити середовище, в якому учасники можуть відчувати себе комфортно, розмовляючи та ставлячи запитання, усвідомлюючи, що можуть виникнути важкі або незручні ситуації. Вони знають, як вирішувати делікатні питання і переконатися, що обговорення залишається шанобливим. Кваліфіковані тренери також $\epsilon$ фрахівцями 3 предметів, хоча не всі тренери мають однакові знання. Деякі можуть мати офріційну освіту, а інші можуть мати досвід роботи в туризмі. Вони могли зазнати стигматизації, дискримінації або спочатку відкинутим за внесок у їхню освіту. Вони можуть мати великий досвід міжнародної роботи або спілкування з різними культурами. Кваліфріковані тренери використовують різноманітні інструменти та ресурси та демонструють свою прихильність до сталого особистого та професійного розвитку. Важливо, щоб досвідчені тренери виявляли справжній інтерес до інших культур. Вони справді віддані культурному та мовному розмаїттю та інклюзії та вірять у переваги вивчення культурного потенціалу. Ряд фракторів може вплинути на ймовірність того, що організація почне здобувати знання про різні культури. Асоціація може не розглядати багатокультурні знання, оскільки ії керівництво не визнає їх цінності або не хоче розвивати багатокультурні знання, коли вона стикається з конкуруючими пріоритетами. Організації, які шукають багатокультурне навчання, можуть не мати доступу до якісних матеріалів та інфрормації, не знають, як знайти чи визначити правильного мультикультурного тренера, або не знають, як забезпечити якість потенційного постачальника. Досвідчені менеджери часто недооцінюють необхідність участі в полікультурному навчанні. Зазвичай вони вважають, що вже мають необхідні навички та практику, або не бачать, як вивчення культурних знань покращує роботу організації. Навіть менеджери, які визнають переваги культурного та мовного розмаїття, часто не розуміють, як культурний потенціал безпосередньо пов'язаний з їхньою організацією. Для невідкладної роботи культурна компетентність часто вважається другим найважливішим срактором в інших конкуруючих пріоритетах. Без зобов'язань організації забезпечувати та сприяти навчанню персоналу на всіх рівнях мультикультурних знань, відповідний час чи ресурси не будуть виділені на навчання.

Хоча опитування до та після дослідження можна легко впроваджувати та керувати ними, щоб отримати уявлення, участь та зна- ння, система моніторингу та довгострокові організаційні переваги вимагають складних стратегій. Численні дослідження, проекти та звіти вимагають, щоб організації нарешті були задоволені відчутними перевагами та цінністю культурного потенціалу освіти. Різні підходи до викладання традиційних знань 3 точки зору лексики, понять, змісту та презентації ускладнюють вироблення стандартів, єдності чи ідентичності. Наразі немає рекомендацій щодо навчання та забезпечення якості. Це означає, що немає контролю чи ідентифікації для забезпечення високої якості програм, заснованих на доказах. У полікультурній освіті також немає системи ідентифрікації тренера. Немає способів запобігти роботі некваліфрікованих чи неякісних тренерів. Погана підготовка може зміцнити переконання та відмінності. Організації та особи з поганим досвідом роботи з неякісними тренерами частіше беруть участь у подальшій освіті. Без офріційної системи ідентифікації культурно компетентних навчальних програм і тренерів $€$ обмежені якісні матеріали та книги від великих видавництв, які базуються на різноманітності та потенціалі мультикультурних контекстів у контексті. Через відсутність центрального місця для розміщення інформації про полікультурну освіту організаціям важко знайти якісні поради та ресурси, розроблені в контексті. Існує дуже мало можливостей для професійного розвитку для тренерів, які хочуть пройти професійний розвиток, або нових тренерів, які шукають спосіб потрапити в цю категорію. $€$ кілька офріційних способів для нових тренерів приєднатися до відділу та менше можливостей для спілкування 3 іншими професіоналами. Також існують обмежені можливості чи місця для профресіоналів для обміну ресурсами та інфрормацією. Різноманітність тісно пов'язана з культурними знаннями, особливо в контексті робочої сили та управління різноманітністю. Всередині керівники та співробітники повинні мати навички керувати різними командами та працювати 3 ними, тоді як за кордоном працівники повинні мати навички взаємодії з кількома клієнтами, клієнтами та зацікавленими сторонами. У контексті управління персоналом та обслуговування клієнтів різноманітність визначається як усі важливі відмінності між людьми, включаючи поняття різноманітності, які необхідно враховувати в конкретній ситуації та ситуації. Часто найважливіші відмінності $€$ найменшими, наприклад, моделі мислення або переконання та цінності. Існує 
багато вимірів різноманітності, які можуть бути набагато меншими, ніж бізнес-діяльність та відносини: грамотність, стать, релігія, стиль спілкування, роль опікуна та стиль управління. У цьому випадку управління різноманітністю зосереджується на визнанні різноманітності та ії впливу на бізнес-операції. Постійний процес, який передбачає розпізнавання ідентичності між співробітниками та клієнтами в усіх основних ссрерах управління бізнесом, комунікаціях, системах та послугах, щоб створити чесну, згуртовану, інклюзивну, креативну та ефрективну організацію. Включення відбувається, коли поважається різноманітність (наприклад, різний вік, культура та стать) і сприяє успіху організації. 3 точки зору організаційної політики та стратегії, використання термінів «різноманітність» та «інтеграція» часто означає різноманітність у багатьох відношеннях, включаючи культуру, інвалідність, гендер і сексуальну орієнтацію. Першим етапом проекту був огляд літератури про культурні компетенції, такі як концептуальна теорія та знання. Література включає огляд і дослідження культурного потенціалу в теорії або теорії, розвиток словникового запасу та різноманітність, а також включення австралійського контексту. Було знайдено багато інструментів для обговорення мультикультурних знань, про які йдеться в літературі. Огляд освітньої програми культурних компетенцій. Після огляду літератури щодо ідей та перспектив, проект включав вивчення традиційних програм підготовки талантів, які зараз пропонуються. Цей етап передбачав створення електронних таблиць і порівняння курсів на основі назви курсу, ціни. Порівняно 3 англо-кельтськими претендентами, корінні жителі та острови Торрес повинні подавати заявки на 35\% більше, кандидати з китайською валютою повинні подавати заявки на додаткові 68\%, італійські імена повинні подавати заявки на додаткові 12\%, а жителі Близького Сходу повинні подавати заявки на 7\% більше заявок.

Іммігранти змушені вдаватися до стратегій, які зменшують їхній акцент на расі чи культурі, наприклад, публікувати своє ім'я та відсутність досвіду роботи чи кваліфрікації - навіть коли мова йде про роботу. Такі проблеми не обмежуються встановленням цін. Співробітники повинні мати рівний доступ до розвитку та прогресу, незалежно від їх культурного чи мовного походження. У багатьох сорерах, включаючи фрінансові послуги Співдружності, гостинність та соціальні послуги, культурне та мовне розмаїття відображається на центральних і технічних посадах, але не має посад вищого керівництва та керівних посад. Різноманітність організації вимагає відображення різноманітності на всіх рівнях організації. На додаток до рівних можливостей працевлаштування, мультикультурна спільнота також вимагає від агенцій надавати продукти та послуги, які відповідають основним потребам мультикультурних та мовних клієнтів. Дослідження та консультації щодо цього звіту та подальша робота щодо доступу, рівності та включеності показують, що державні послуги, підприємства та державний сектор не забезпечують справедливих результатів австралійським споживачам, які визнають культурне та мовне розмаїття. Полікультурна компетентність майбутніх орахівців (екскурсоводів) у ВНЗ $€$ важливим педагогічним завданням. На університетському рівні мультикультурні знання вимагають точних дій та відданості реалізації та оцінці, щоб створити робоче місце, яке є культурно та мовно різноманітним. Наприклад, вищі навчальні заклади з високим рівнем знань про мультикультуралізм мають стратегії письма, які відображають природну упередженість; і мають методи, які допомагають їм зрозуміти культурні особливості громад, яким вони служать. Політика сприяння культурному та мовному розмаїттю може посилатися на документи або може бути пов'язана з планом, таким як мультикультурний план доступу та правосуддя. Хоча формат може відрізнятися від організації до організації, політика якості культурного та мовного розмаїття має включати спільну мету та мету, а також розвиток усіх видів діяльності, ініціатив чи результатів. Важливо встановити зручний і ефрективний графрік і визначити відповідальний відділ або керівника університету, відповідального за все. Програми навчання мультикультурним знанням допомагають особам і організаціям розвивати навички та інструменти, необхідні для навчання, управління та розвитку різноманітних груп, і $є$ важливою частиною багатокультурного підходу. Мультикультурна підготовка знань, яку пропонується включити в програми підготовки майбутніх фрахівців з туристичної підтримки (керівництво), суттєво відрізняється за змістом, методом проведення, тривалістю та вартістю. Деякі навчальні програми $€$ частиною або специфрікою навчальної програми або зосереджені на певних культурних спільнотах чи мовах. Без фрормальних стандартів чи ідентичностей словниковий запас у полі- 
Кількість закладів вищої освіти в Україні

\begin{tabular}{|c|c|c|c|}
\hline Навчальний рік & $\begin{array}{c}\text { Кількість закладів } \\
\text { вищої освіти }\end{array}$ & $\begin{array}{c}\text { \% до попереднього } \\
\text { навчального року }\end{array}$ & $\begin{array}{c}\text { \% до 2014/2015 } \\
\text { навчального року }\end{array}$ \\
\hline $2014 / 2015$ & 664 & -- & 99,25 \\
\hline $2015 / 2016$ & 659 & 99,25 & 98,95 \\
\hline $2016 / 2017$ & 657 & 99,70 & 99,55 \\
\hline $2017 / 2018$ & 661 & 100,61 & 98,19 \\
\hline $2018 / 2019$ & 652 & 98,64 & 93,22 \\
\hline $2019 / 2020$ & 619 & 94,94 & \\
\hline
\end{tabular}

Джерело: [5] адаптовано автором

культурних знаннях розвивався нерівномірно. Хоча навчальна програма рекламується під різними назвами, культурна компетентність часто використовується українськими та міжнародними експертами.

Враховуючи питання підготовки майбутніх фрахівців в проаналізуємо наявність вищих навчальних закладів в країні, при допомозі даних таблиці 1.

Кількість закладів вищої освіти в Україні за період з 2014 по 2020 рр. зменшилася майже на 7 відсотків, або на 45 навчальних закладів. Дана ситуація $€$ наслідком кількох аспектів, а саме:

- 32014 р. в країні іде війна, в результаті чого частина навчальних закладів АР Крим та Донецької і Луганської областей перестали існувати;

- в 2019 р. частина закладів закрилася через необхідну кількість здобувачів вищої освіти.
Таким чином, кількість закладів вищої освіти в Україні має тенденцію до зменшення і мабуть ця тенденція продовжуватиме бути і дальше.

Маючи багато невідкладних питань та проблем в країні існує почасти безкоштовне навчання. Частка здобувачів навчаються за рахунок держави, хоча з різних причин кількість місць державного замовлення щороку змінюється. Дана ситуація відбувається 3 врахуванням необхідності навчання на деяких дуже необхідних для країни спеціальностях. Враховуючи наявні статистичні дані ми можемо дослідити дане питання на прикладі державного замовлення на підготовку фахівців у галузі знань 01 «Освіта/Педагогіка» (табл. 2).

Зміна обсягів державного замовлення підготовки фрахівців проаналізуємо на прикладі галузі знань 01 «Освіта/Педагогіка» за період 2016-2019 рр. За даною галуззю знань обсяги

Зміна обсягів державного замовлення на підготовку фахівців

Таблиця 2 у галузі знань 01 «Освіта/Педагогіка» за період 2016-2019 рр.

\begin{tabular}{|l|c|c|c|c|c|}
\hline \multirow{2}{*}{ Роки } & \multicolumn{2}{|c|}{$\begin{array}{c}\text { Освітньо-кваліфікаційний рівень } \\
\text { ступінь вищої освіти }\end{array}$} & $\begin{array}{c}\text { \% до } \\
\text { попереднього } \\
\text { року }\end{array}$ & $\begin{array}{c}\text { \% до } \\
\text { 2016 року }\end{array}$ \\
\cline { 2 - 4 } & Бакалавр & Магістр & Усього & -- & \\
\hline 2016 усього: & 11917 & 5642 & 17559 & -- & \\
\hline денна & 9938 & 4419 & 14357 & -- & \\
\hline заочна & 1979 & 1223 & 3202 & 116,56 & 116,56 \\
\hline 2017 усього: & 12283 & 8183 & 20466 & 115,08 & 115,08 \\
\hline денна & 10226 & 6296 & 16522 & 123,17 & 123,17 \\
\hline заочна & 2057 & 1887 & 3944 & 103,66 & 120,82 \\
\hline 2018 усього: & 11706 & 9509 & 21215 & 102,92 & 118,44 \\
\hline денна & 9653 & 7352 & 17005 & 106,74 & 131,48 \\
\hline заочна & 2053 & 2157 & 4210 & 103,59 & 125,27 \\
\hline 2019 усього: & 12982 & 9015 & 21997 & 98,01 & 116,09 \\
\hline денна & 10362 & 6305 & 16667 & 126,60 & 166,46 \\
\hline заочна & 2620 & 2710 & 5330 & 93,42 & 117,03 \\
\hline 2020 прогноз усього: & 13240 & 7310 & 20550 & 101,13 & 117,40 \\
\hline денна & 11015 & 5840 & 16855 & 69,32 & 115,40 \\
\hline заочна & 2225 & 1470 & 3695 & & \\
\hline
\end{tabular}


Таблиця 3

Обсяг вступу абітурієнтів за галуззю знань 01 «Освіта/Педагогіка» за період 2016-2019 рр.

\begin{tabular}{|c|c|c|c|c|c|}
\hline \multirow[t]{2}{*}{ Роки } & \multicolumn{3}{|c|}{$\begin{array}{c}\text { Освітньо-кваліфікаційний рівень/ступінь } \\
\text { вищої освіти }\end{array}$} & \multirow{2}{*}{$\begin{array}{c}\text { \% до } \\
\text { попереднього } \\
\text { року }\end{array}$} & \multirow{2}{*}{$\begin{array}{c}\% \text { до } \\
2016 \text { року }\end{array}$} \\
\hline & Бакалавр & Магістр & Усього & & \\
\hline 2016 усього: & 23704 & 10986 & 34690 & - & - \\
\hline денна & 12319 & 5989 & 18308 & - & - \\
\hline заочна & 11385 & 4997 & 16382 & - & - \\
\hline 2017 усього: & 27425 & 23341 & 50766 & 146,34 & 146,34 \\
\hline денна & 12783 & 8197 & 20980 & 114,59 & 114,59 \\
\hline заочна & 14642 & 15144 & 29786 & 181,82 & 181,82 \\
\hline 2018 усього: & 30942 & 24439 & 55381 & 109,09 & 159,65 \\
\hline денна & 12372 & 9494 & 21886 & 104,22 & 119,43 \\
\hline заочна & 18570 & 14945 & 33515 & 112,52 & 204,58 \\
\hline 2019 усього: & 29388 & 23961 & 53349 & 96,33 & 153,79 \\
\hline денна & 18996 & 11422 & 30418 & 139,11 & 166,15 \\
\hline заочна & 10392 & 12539 & 22931 & 68,42 & 139,98 \\
\hline
\end{tabular}

Джерело: [5] адаптовано автором

державного замовлення мають не значні коливання в ту чи іншу сторону, але загалом враховуючи необхідність та значущість даної підготовки ситуація не може бути іншою. Хоча загалом в закладах вищої освіти в порівнянні з 2016 р. обсяг державного замовлення підготовки фрахівців зріс і для бакалаврів і для магістрів, хоча прогнозні данні 2020 р. даний обсяг знизився на заочній формі навчання, особливо магістрів, що $€$ наслідком тощо, що молоді люди відтягують час служби у Збройних силах України.

Хоча кількість студентів майже стабільна, складається ситуація, що абітурієнтів набагато більше. Враження, що при відборі осіб, які хочуть і можуть навчатися набагато більше $€$ помилковою і для того, щоб вивчити дане питання скористаємося даними таблиці 3.

Обсяг вступу абітурієнтів за галуззю знань 01 «Освіта/Педагогіка» за період 2016-2019 рр. свідчить про наступне:

- 3 одного боку кількість абітурієнтів якби зростає, а з іншого абітурієнти подають максимальну кількість заяв на вступ, шукаючи таким чином місця державного замовлення;

- знаючи тенденцію до збільшення вартості плати за навчання абітурієнти хочуть як най швидше навчатися і отримувати вищу освіту.
Отже, аналізуючи кількість абітурієнтів, що вступають у вищі навчальні заклади можна відмітити їх зростання, що є позитивним, але одночасно це ми аналізуємо абітурієнтів за галуззю знань 01 «Освіта/Педагогіка», а це означає, що передумовою $є$ підтримка держави у рівні оплати праці фрахівців даної спеціальності, що відрізняється стабільністю в порівнянні з іншими профресіями.

Таким чином, враховуючи проблеми нинішнього суспільства на підприємствах сорери гостинності необхідно враховувати наступні аспекти сучасності:

- викладачі вищих навчальних закладів постійно підвищувати рівень мультикатурної компетентності з метою її поліпшення у здобувачів вищої освіти і відповідно фахівців даних підприємств;

- керівникам підприємства туризму 3 метою підвищення рівня ефективності маркетингової діяльності і загалом підприємства необхідно працевлаштовувати кваліфікованих працівників;

- необхідно збільшувати кількість державного замовлення в вищих навчальних закладах $з$ метою збільшення кількості кваліфрікованих працівників в туризмі.

\section{СПИСОК ВИКОРИСТАНИХ ДЖЕРЕЛ:}

1. Закон України «Про освіту». URL: https://zakon.rada.gov.ua/go/2145-19

2. Ізбаш С.С., Бутурліна Ю.О. Управлінська підтримка зростання професійної майстерності педагога. Педагогіка, психологія та медико-біологічні проблеми фрізичного виховання і спорту. 2009. № 3. С. 56-59. 
3. Борова Т. А. Теоретичні засади адаптивного управління професійним розвитком науково-педагогічних працівників вищого навчального закладу : монографрія. Харків : Компанія СМІT, 2011. 384 с.

4. Єльникова Г. Технологія адаптивного управління персоналом організації. Науковий вісник Інституту професійно-технічної освіти НАПН України. Серія : Профресійна педагогіка. 2011. № 1. С. 8-14.

5. Державна служба статистики (2020). Освіта в Україні: виклики та перспективи. Інформаційно-аналітичний збірник. URL: https://mon.gov.ua/storage/app/media/zagalna\%20serednya/serpneva-konferencia/2020/met

\section{REFERENCES:}

1. Zakon Ukrainy «Pro osvitu». Retrieved from: https://zakon.rada.gov.ua/go/2145-19

2. Izbash S.S., Buturlina Y.O. (2009) Upravlinska pidtrymka zrostannia profesiinoi maisternosti pedahoha [Management support for the growth of professional skills of teachers]. Pedagogy, psychology and medical and biological problems of physical education and sports, no. 3, pp. 56-59.

3. Borova T.A. (2011) Teoretychni zasady adaptyvnoho upravlinnia profesiinym rozvytkom naukovo-pedahohichnykh pratsivnykiv vyshchoho navchalnoho zakladu: monohrafiia [Theoretical principles of adaptive management of professional development of scientific and pedagogical workers of higher education: monograph]. Kharkiv: SMITH Company, $384 \mathrm{p}$.

4. Yelnikova G.( 2011) Tekhnolohiia adaptyvnoho upravlinnia personalom orhanizatsii [Technology of adaptive personnel management of the organization]. Scientific Bulletin of the Institute of Vocational Education of the National Academy of Pedagogical Sciences of Ukraine. Series: Professional pedagogy, no. 1, pp. 8-14.

5. Derzhavna sluzhba statystyky Ukrainy (2020) [Education in Ukraine: challenges and prospects]. Information and analytical collection. Kyiv. Retrieved from: https://mon.gov.ua/storage/app/media/zagalna\%20serednya/serpneva-konferencia/2020/met 